\title{
Clot in transit: a case of acute pulmonary embolism
}

\author{
Jose Ruiz-Morales, ${ }^{1}$ William Kogler, ${ }^{2}$ Maedeh Ganji, ${ }^{1}$ Srinivasan Sattiraju ${ }^{1}$
}

${ }^{1}$ Cardiology, University of Florida College of MedicineJacksonville, Jacksonville, Florida, USA

${ }^{2}$ Internal Medicine, UF Health Jacksonville, Jacksonville, Florida, USA

\section{Correspondence to} DrWilliam Kogler; william.kogler@jax.ufl.edu

Accepted 1 July 2020

\section{DESCRIPTION}

A 53-year-old woman with a previous medical history of hypertension presented to the hospital with shortness of breath for 2 weeks. Transthoracic echocardiogram (TTE) revealed findings suggestive of chronic cardiomyopathy with decreased left ventricular systolic function. Right ventricle was enlarged and hypokinetic. TTE also revealed a long serpiginous echogenic density suggestive of a thrombus in the right atrium (figure 1). In subsequent images, the thrombus transits through the tricuspid valve into the right ventricle (online supplementary video S1). CT angiography revealed acute pulmonary embolism (PE) in the upper lobe of the left lung and for that reason, anticoagulation with heparin was initiated. She remained haemodynamically stable and underwent hypercoagulable workup, which was negative. Patient was managed with apixaban along with guideline-based therapy for chronic cardiomyopathy and was subsequently discharged home.

$\mathrm{PE}$ is a common condition with an annual rate of 1-2 per $1000^{1}$ and is associated with high morbidity and mortality. CT pulmonary angiography is the current standard of care for diagnosis with a sensitivity of $83 \%$ and specificity of $96 \%{ }^{2}$ TTE for diagnosis of PE is usually of limited value, however, it can be useful for classification and prognosis. This case represents an exceptionally rare finding of capturing a thrombus in real time as it makes its way from right atrium to the right ventricle through the tricuspid valve. This phenomenon has been referred to as a "clot

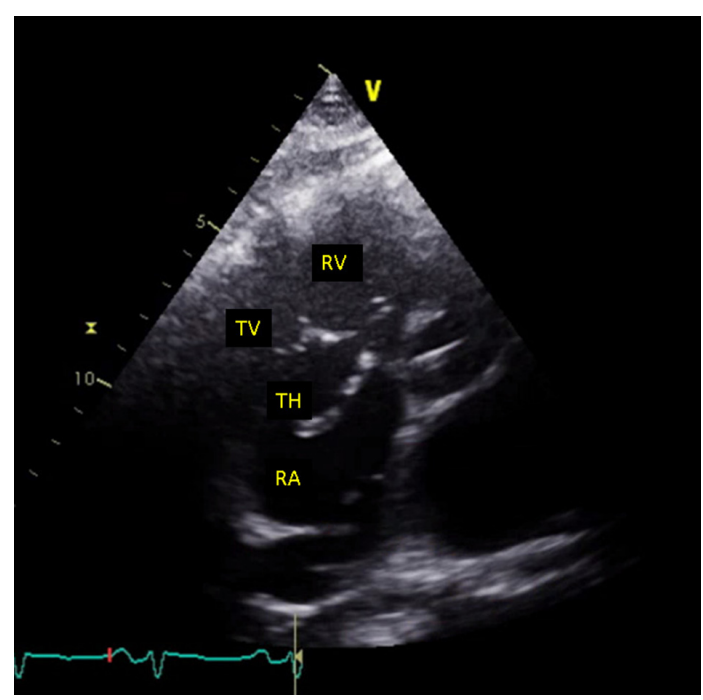

Figure 1 Transthoracic echocardiogram; subcostal view: this image reveals a long, serpiginous echogenic density in the right atrium. $\mathrm{RA}$, right atrium; $\mathrm{RV}$, right ventrical; $\mathrm{TV}$, tricuspid valve; $\mathrm{TH}$, thrombus. in transit', which is defined as a right heart thrombus that is not attached to any intracardiac structure. ${ }^{3}$ It is a unique finding that is rarely documented on imaging studies. When present, it is almost uniformly diagnosed with echocardiography. It is an important clinical entity as it carries an in-hospital mortality rate of $45 \%$, usually from a subsequent $\mathrm{PE}$, or in rare cases a systemic emboli when intracardiac shunt is present. ${ }^{3}$ Treatment should be focused on treating PE with anticoagulation therapy for at least 3-6 months, although in some cases depending on clot burden and patient haemodynamics, surgery or thrombolytics may be more appropriate. ${ }^{3}$ This case demonstrates the benefit of multimodal imaging in the diagnosis and treatment of $\mathrm{PE}$, and the unique phenomenon is known as clot in transit.

\section{Learning points}

- This case demonstrates a venous thromboembolism as it transits from the right atrium to the right ventricle on its way to the pulmonary artery. This unique video is a rare, real-time look at this process that has been identified as a clot in transit.

- Multimodal imaging should be used in order to not only diagnosis pulmonary embolism (PE) but also to risk stratify and classify severity of $\mathrm{PE}$ in order to more appropriately treat these patients.

Acknowledgements The authors acknowledge Ms Rachel Sharp, RDCS for her expertise in ultrasonography.

Contributors JR-M contributed to this manuscript by providing direct patient care, writing the manuscript, interpreting/obtaining imaging; MG contributed by assisting in writing manuscript/editing; WK contributed by assisting in writing manuscript/editing and SS contributed by providing direct patient care, interpreting imaging and editing manuscript.

Funding The authors have not declared a specific grant for this research from any funding agency in the public, commercial or not-for-profit sectors.

Competing interests None declared.

Patient consent for publication Obtained.

Provenance and peer review Not commissioned; externally peer reviewed.

\section{REFERENCES}

1 van der Hulle T, Dronkers CEA, Klok FA, et al. (Leiden University Medical Center, Leiden, The Netherlands). Recent developments in the diagnosis and treatment of pulmonary embolism. (Review). J Intern Med 2016;279:16-29.

2 Moore AJE, Wachsmann J, Chamarthy MR, et al. Imaging of acute pulmonary embolism: an update. Cardiovasc Diagn Ther 2018;8:225-43.

3 Shah DP, Min JK, Raman J, et al. Thrombus-in-transit: two cases and a review of diagnosis and management. J Am Soc Echocardiog 2007;20:1219.e6-1219.e8 
Copyright 2020 BMJ Publishing Group. All rights reserved. For permission to reuse any of this content visit https://www.bmj.com/company/products-services/rights-and-licensing/permissions/

BMJ Case Report Fellows may re-use this article for personal use and teaching without any further permission.

Become a Fellow of BMJ Case Reports today and you can:

- Submit as many cases as you like

- Enjoy fast sympathetic peer review and rapid publication of accepted articles

Access all the published articles

Re-use any of the published material for personal use and teaching without further permission

Customer Service

If you have any further queries about your subscription, please contact our customer services team on +44 (0) 2071111105 or via email at support@bmj.com.

Visit casereports.bmj.com for more articles like this and to become a Fellow 